OPEN ACCESS

Edited by:

Oliver Kepp,

U1138 Centre de Recherche des Cordeliers (CRC)(INSERM), France

Reviewed by:

Bernhard Riedel,

Peter MacCallum Cancer Centre,

Australia

Zhi-Fu Wu,

Kaohsiung Medical University, Taiwan

*Correspondence:

Ryungsa Kim

ryu@hbc-center.com

Specialty section:

This article was submitted to

Surgical Oncology,

a section of the journal

Frontiers in Oncology

Received: 15 October 2021

Accepted: 17 January 2022

Published: 09 February 2022

Citation:

Kim R, Kawai A, Wakisaka M and Kin T (2022) Current Status and Prospects of Anesthesia and Breast Cancer: Does Anesthetic Technique Affect Recurrence and Survival Rates in Breast Cancer Surgery?

Front. Oncol. 12:795864. doi: 10.3389/fonc.2022.795864

\section{Current Status and Prospects of Anesthesia and Breast Cancer: Does Anesthetic Technique Affect Recurrence and Survival Rates in Breast Cancer Surgery?}

\author{
Ryungsa Kim $^{1 *}$, Ami Kawai ${ }^{1}$, Megumi Wakisaka ${ }^{1}$ and Takanori Kin ${ }^{2}$ \\ ${ }^{1}$ Department of Breast Surgery, Hiroshima Mark Clinic, Hiroshima, Japan, ${ }^{2}$ Department of Breast Surgery, Hiroshima City \\ Hospital, Hiroshima, Japan
}

The relationship between the anesthetic technique and cancer recurrence has not yet been clarified in cancer surgery. Surgical stress and inhalation anesthesia suppress cellmediated immunity (CMI), whereas intravenous (IV) anesthesia with propofol and regional anesthesia (RA) are known to be protective for CMl. Surgical stress, general anesthesia (GA) with inhalation anesthesia and opioids contribute to perioperative immunosuppression and may increase cancer recurrence and decrease survival. Surgical stress and GA activate the hypothalamic-pituitary-adrenal axis and release neuroendocrine mediators such as cortisol, catecholamines, and prostaglandin $E_{2}$, which may reduce host defense immunity and promote distant metastasis. On the other hand, IV anesthesia with propofol and RA with paravertebral block or epidural anesthesia can weaken surgical stress and GA-induced immunosuppression and protect the host defense immunity. IV anesthesia with propofol and RA or in combination with GA may reduce cancer recurrence and improve patient survival compared to GA alone. We review the current status of the relationship between anesthesia and breast cancer recurrence using retrospective and prospective studies conducted with animal models and clinical samples, and discuss the future prospects for reducing breast cancer recurrence and improving survival rates in breast cancer surgery.

Keywords: breast cancer, anesthetic technique, recurrence, survival, immune response

Abbreviations: ALND, axillary lymph node dissection; ARF6, adenosine diphosphate-ribosylation factor 6; BCS, breast-
conserving surgery; CMI, cell-mediated immunity; CTC, circulating tumor cell; CTL, cytotoxic T lymphocyte; DEX,
dexmedetomidine; ER, estrogen receptor; ERK, extracellular signal-regulated kinase; GA, general anesthesia; HER-2,
human epidermal growth factor receptor 2; HIF-1 $\alpha$, hypoxia-inducible factor-1 $\alpha$; HPA, hypothalamic-pituitary-adrenal;
HR, hormone receptor; IL, interleukin; IVA, intravenous anesthesia; LA, local anesthesia; MDSC, myeloid-derived suppressor
cell; miR, micro RNA; MMP, matrix metalloproteinase; MOR, $\mu$-opioid receptor; MT, mastectomy; mTOR, mechanistic target
of rapamycin; NF-KB, nuclear factor $\mathrm{\kappa B}$; NK, natural killer; NLR, neutrophil-to-lymphocyte ratio; NSAID, nonsteroidal anti-
inflammatory drug; OS, overall survival; PGE 2 , prostaglandin $\mathrm{E}_{2}$; PVB, paravertebral block; RA, regional anesthesia; RCT,
randomized controlled trial; RFS, recurrence-free survival; SLNB, sentinel lymph node biopsy; SNS, sympathetic nervous
system; TDSF, tumor-derived soluble factor; Th, T helper; TIVA, total intravenous anesthesia; TN, triple negative; TNF- $\alpha$,
tumor necrosis factor- $\alpha$; TPVB, total paravertebral block; Treg, regulatory T cell; VEGF, vascular endothelial growth factor. 


\section{INTRODUCTION}

Over the past two decades, the relationship between anesthesia and cancer recurrence has been a controversial issue in the field of oncological surgery because surgical stress and intraoperative anesthesia impair host immunity (1). The first report on anesthesia and cancer recurrence, published in 2000, describes a retrospective analysis of patients with cutaneous melanoma (2). In that study, the survival rate of patients who received local anesthesia (LA) was higher than that of patients who received general anesthesia (GA), suggesting that LA reduces the recurrence of melanoma relative to GA (2). This finding reflects the impairment of cell-mediated immunity (CMI) and host immune responses by inhalation GA (3). Indeed, several preclinical models have shown that inhaled anesthetics inhibit natural killer (NK) cell- and T lymphocyte-mediated immunity, resulting in increased metastasis $(4,5)$. Immunosuppression by inhalation anesthesia is mediated by the stimulation of the hypothalamic-pituitaryadrenal (HPA) axis, which releases neuroendocrine mediators such as catecholamines, prostaglandin $\mathrm{E}_{2}\left(\mathrm{PGE}_{2}\right)$, cytokines, and cortisol. Other neuroendocrine mediators, such as interleukin 6 (IL-6) and matrix metalloproteinases (MMPs), are also secreted and play critical roles in the regulation of tumor growth and angiogenesis (6). The impairment of CMI may reactivate micrometastases that are already disseminated at the time of surgery, increasing the frequencies of cancer recurrence and distant metastasis (6). In contrast, LA allows the maintenance of spontaneous breathing during surgery and has a weaker immunosuppressive effect than does GA (7).

Other factors that can cause immunosuppression during cancer surgery include surgical stress and opioid use. Surgical stress is limited by the size of the operative field, duration of the operation, and amount of blood loss (8). Opioids are commonly used in combination with inhalation anesthetics as analgesics and sedatives for GA, but non-synthetic and synthetic opioids can suppress CMI, depending on the dose and duration of use (9). In contrast, intravenous anesthesia (IVA) with propofol protects CMI $(4,10)$, as does regional anesthesia (RA) with paravertebral block (PVB) or epidural anesthesia. RA blocks afferent neurotransmitter pathways from peripheral nerves to the central nervous system and the efferent activation of the sympathetic nervous system (SNS), thereby reducing the release of neuroendocrine mediators such as glucocorticoids and allowing the minimization of opioid use (11).

Retrospective studies of anesthesia and cancer recurrence have yielded positive and negative results, depending on the type of cancer and the anesthetic technique used. Several prospective randomized controlled trials (RCTs) are underway, and preliminary results suggest that the effects of anesthesia on cancer recurrence and survival differ depending on the type of cancer. In this review, we examine the effect of the anesthetic technique used during breast cancer surgery on breast cancer recurrence and survival, and discuss the current status of and future prospects for anesthesia and breast cancer.

\section{EFFECTS OF SURGICAL STRESS AND ANESTHESIA ON IMMUNE FUNCTION AND BREAST CANCER PROGRESSION}

Stress caused by surgery and anesthetics is believed to trigger changes in the immune system, the host defense, and tumor formation. The constellation of anesthesia, stress, and immunosuppression effects on breast cancer recurrence is illustrated in Figure 1. The hypothetical balancing of recurrencepromoting and -inhibiting factors related to breast cancer surgery is shown in Figure 2.

\section{Surgical Stress}

In general, the invasiveness of surgery, postoperative pain, and intraoperative bleeding are stress factors in cancer surgery. For thoracic and abdominal surgeries, long operative times, excessive invasiveness, and massive blood loss are major stress factors leading to decreased immunity in patients with cancer. As surgery alters the microenvironments of the nervous, endocrine, inflammatory, and immune systems (12), the stress response induced by surgery may activate angiogenesis and promote tumor growth (13-15). Breast cancer surgery types are breast-conserving surgery (BCS), mastectomy (MT) with or without subsequent reconstruction, sentinel lymph-node biopsy (SLNB), and axillary lymph-node dissection (ALND). $\mathrm{BCS}$ is less invasive than MT and yields higher survival rates (16-18), and SLNB is less invasive than ALND. These surgeries usually take 1-2 hours, and those that do not involve reconstruction cause less blood loss. Relative to thoracic and abdominal surgeries, breast cancer surgery is minimally invasive due to its de-escalation based on the concept that breast cancer is a systemic disease, and to the development of adjuvant and neoadjuvant chemotherapies. Nevertheless, surgical resection, even in patients with breast cancer, can increase the expression of MMP-9 and vascular endothelial growth factor (VEGF), which may promote tumor growth and metastasis, as documented in some xenograft models of breast cancer (19). Plasma VEGF levels are increased by surgical stress during MT (13), and plasma transforming growth factor- $\beta$ levels have been shown to increase and to be associated with lung metastasis after MT in animal models (20). In patients with breast cancer, the acceleration of metastasis due to the proliferation of distant and dormant micrometastases after surgical resection has been observed (21).

\section{Inhalation Anesthesia}

In anesthesia-induced immunosuppression, inhalation anesthetics such as sevoflurane suppress CMI and promote tumor cell proliferation and angiogenesis. Sevoflurane induces the apoptosis of $\mathrm{T}$ lymphocytes and upregulates the expression of hypoxiainducible factor- $1 \alpha$ (HIF-1 $\alpha)$ in vitro; other inhalation anesthetics, including isoflurane and desflurane, upregulate HIF- $1 \alpha$ expression in vitro and in vivo $(5,22)$. Sevoflurane has also been shown to increase 
A
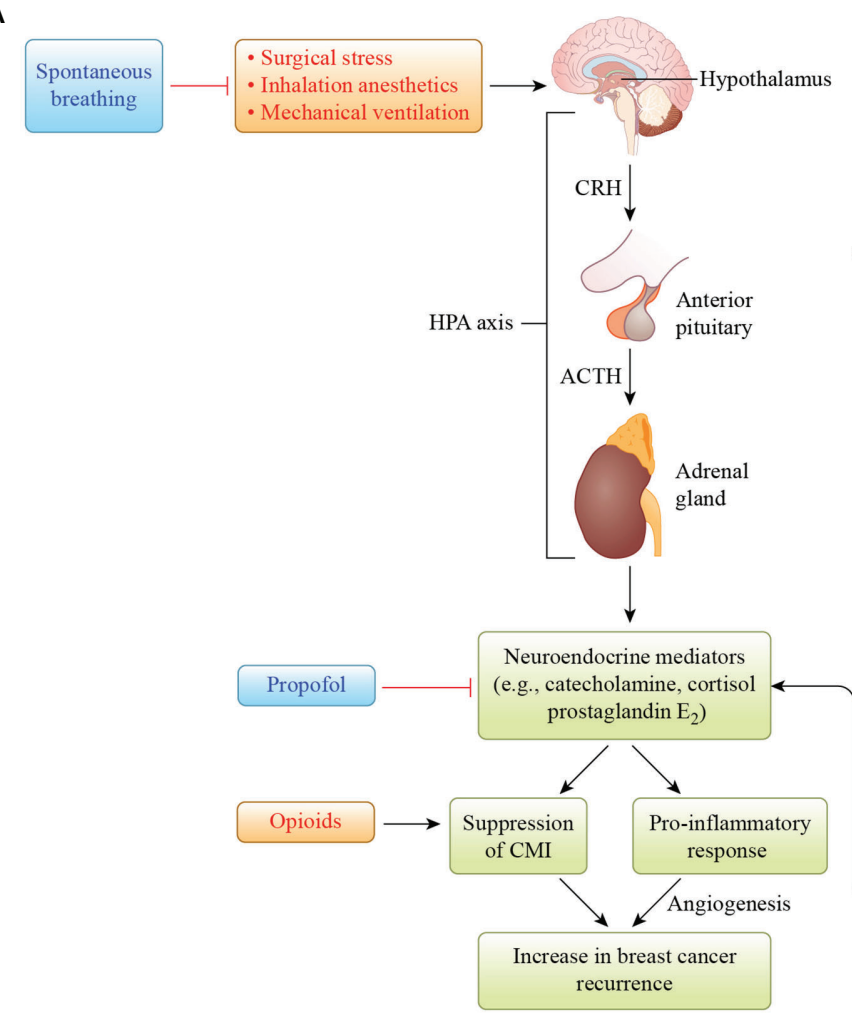

B

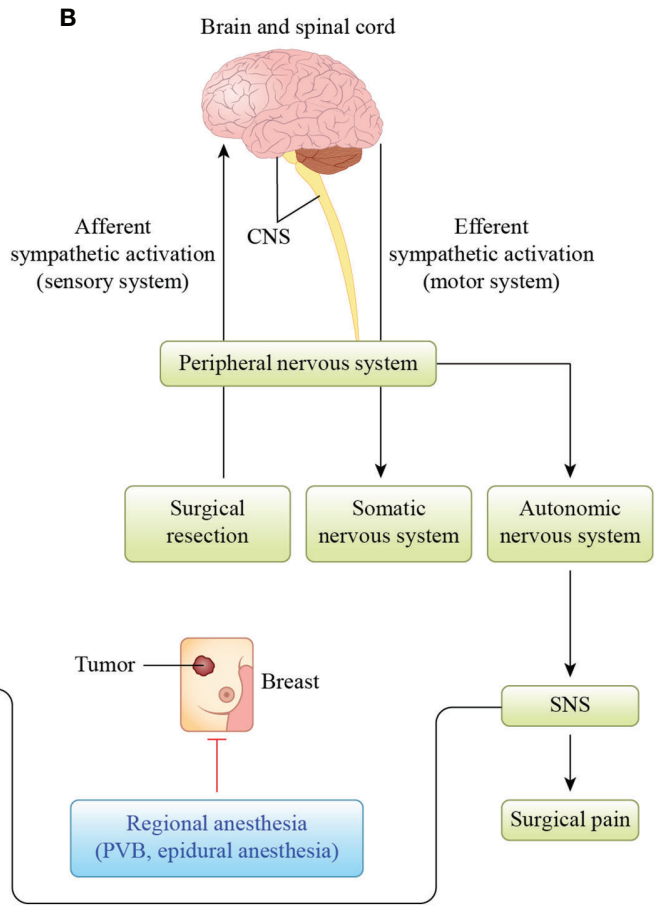

FIGURE 1 | Illustration of the hypothesis that hypothalamus-pituitary-adrenal (HPA) axis and sympathetic nervous system (SNS) activation by surgical stress, inhalation anesthetics, and mechanical ventilation is involved in increased breast cancer recurrence. (A) Activation of the HPA axis results in the release of neuroendocrine mediators such as catecholamine, cortisol, and prostaglandin $\mathrm{E}_{2}$. These mediators suppress cell-mediated immunity (CMI), resulting in host immunosuppression, and produce pro-inflammatory cytokines to induce angiogenesis, which has been associated with increased breast cancer recurrence. Propofol protects against CMI suppression mediated by neuroendocrine mediators, whereas opioids suppress CMI. (B) When breast cancer surgery activates the afferent nervous system from the peripheral to the central nervous system (CNS), it activates the efferent nervous system from the CNS to the peripheral nervous system, autonomic nervous system, and sympathetic nervous system (SNS), which releases neuroendocrine mediators. Regional anesthesia, such as paravertebral blockade (PVB), or epidural anesthesia inhibits the SNS-induced release of neuroendocrine mediators. Reciprocal activation of the HPA axis and SNS by surgical stress and/or inhalation anesthesia may increase breast cancer recurrence. $\mathrm{CRH}$, corticotropinreleasing hormone; $\mathrm{ACTH}$, adrenocorticotropic hormone.

the levels of MMP-3 and -9 in patients undergoing breast cancer surgery (23). Surgical stress and inhalation anesthesia may increase distant metastasis in patients with cancer by activating the HPA axis and the SNS via the release of neuroendocrine mediators such as cortisol, catecholamines, and $\mathrm{PGE}_{2}$. Sevoflurane increases the proliferation, migration, and invasion of estrogen receptor (ER)positive and -negative breast cancer cells (24). Furthermore, serum from patients who received propofol and PVB, but not from those who received sevoflurane and opioids, for breast cancer surgery inhibited the growth of ER-negative breast cancer cells in vitro (25). On the other hand, a recent study showed that sevoflurane, especially at high concentrations, inhibits the migration, invasion, and epithelial-mesenchymal transition (EMT) of breast cancer cells, mediated by the upregulation of micro-RNA (miR)-139-5p and down-regulation of adenosine diphosphate-ribosylation factor 6 (ARF6) due to miR-139-5p-ARF6 binding in vitro (26). These effects are based on the involvement of miR-139-5p in the metastatic processes of breast cancer cell migration and invasion, and the key functional role of ARF6 in tumor angiogenesis $(27,28)$.

\section{Opioids}

Opioids such as morphine stimulate the growth of tumor cells in vitro, and synthetic opioids such as fentanyl and remifentanil also inhibit CMI. Most opioids inhibit the proliferation of $\mathrm{T}$ lymphocytes (29). Morphine inhibits NK cell cytotoxicity and T cell proliferation and differentiation, promotes $\mathrm{T}$ lymphocyte apoptosis, and decreases the expression of the lipopolysaccharide receptor toll-like receptor 4 on macrophages in vitro and in vivo (29-32). Similarly, fentanyl was found to decrease NK cell cytotoxicity, resulting in lung metastasis, in an animal model (33), but to increase regulatory $\mathrm{T}$ cell (Treg) expression in patients who had undergone breast cancer surgery (34). Remifentanil has also been shown to inhibit NK cell cytotoxicity and $\mathrm{T}$ lymphocyte proliferation in a rat model 


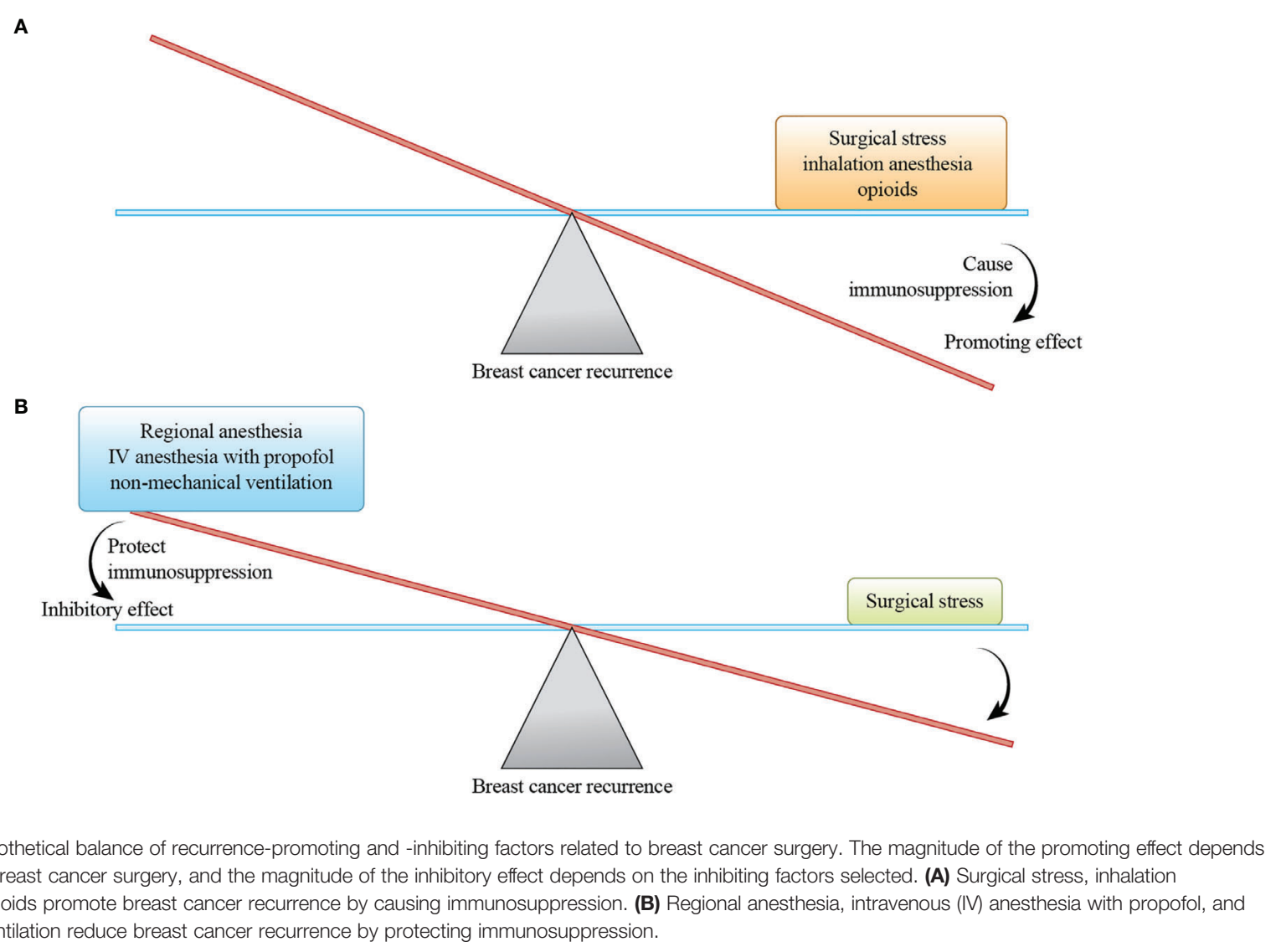

(35). Opioid analgesics may affect tumor development by modulating cell proliferation and cell death (36-38). Various immunocompetent cells express $\mu$-opioid receptors (MORs) and induce apoptosis under opioid alkaloid treatment, suggesting that opioids suppress the immune response (39). In contrast, the overexpression of MORs, which promotes tumor growth and metastasis, has been observed in several human cancers (40).

The tumor growth-promoting effects of opioids are mediated by a signaling cascade involving Akt and extracellular signal-regulated kinase (ERK), whereas their death-promoting effects are mediated by the inhibition of nuclear factor $-\kappa \mathrm{B}(\mathrm{NF}-\kappa \mathrm{B})$, increased expression of Fas, stabilization of p53, and activation of p38 and c-Jun-Nterminal kinase (39). In a recent study, morphine promoted angiogenesis and tumor cell proliferation in recurrent breast tumors in nude mice after breast cancer surgery, likely with the involvement of the PI3K/c-Myc signaling pathway (41). In a triplenegative (TN) breast cancer xenograft model, morphine promoted TN breast cancer metastasis and angiogenesis, and the non-steroidal anti-inflammatory drug (NSAID) ketorolac inhibited these effects, possibly due to its enhancement of thrombospondin-1 synthesis and inactivation of the PI3K/Akt/c-Myc pathway (42).

Opioid-induced cell proliferation and cell death are thought to depend on the opioid concentration and duration of exposure. In vitro, low concentrations and single doses of opioids promote tumor growth, whereas chronic use and high opioid concentrations inhibit this growth (43). Clinically useful doses of morphine have been shown to promote tumor neovascularization and progression in xenograft models of human breast cancer (38), and to promote angiogenesis and the progression of ER-negative breast cancer in vitro and in vivo (44). Morphine also stimulates the proliferation of vascular endothelial cells, which is mediated by the mitogen-activated protein kinase pathway, in vitro (45). MORs are thought to play important roles in angiogenesis and carcinogenic signaling. On the other hand, the preoperative and postoperative use of morphine as analgesia was found to decrease the tumor-promoting effects of surgery (46) and to significantly suppress the surgery-induced increase in corticosterone production (47) in rat models. These results suggest that preoperative morphine administration plays an important role in the prevention of surgery-induced metastasis. Indeed, a recent study showed that increases in intraoperative opioid doses improved recurrence-free survival (RFS), but not overall survival (OS), in patients with TN breast cancer (48). The authors explained this effect by noting that the expression of opioid receptors in tumor and immune cells was consistent with the protective effect of opioid agonists, with no or decreased expression of protumor receptors and elevated expression of antitumor receptors (48). 


\section{Tramadol and Dexmedetomidine}

Analgesic use after breast cancer surgery may also affect longterm outcomes. Tramadol is an atypical opioid analgesic that has shown antitumor effects on breast cancer cells in vitro and in vivo $(49,50)$. The mechanism by which tramadol exerts these effects involves cell cycle arrest and the induction of apoptosis via ERK, due to the decreased expression of 5-hydroxytryptamine $2 \mathrm{~B}$ receptor and transient receptor potential vanilloid-1, as demonstrated by in-vitro experiments (49). In vivo, tramadol administration decreased the expression of inflammatory cytokines such as IL- 6 and tumor necrosis factor- $\alpha$ (TNF- $\alpha$ ), which are involved in tumor growth and invasion, and maintained NK cell activity, unlike morphine (50). Tramadol activates the host immune system by increasing lymphocyte proliferation and NK cell activity in patients with cancer (29). Furthermore, a retrospective analysis showed that tramadol use was associated with reduced breast cancer recurrence and mortality in patients who had undergone breast cancer surgery (49).

Dexmedetomidine (DEX) is a selective $\alpha 2$ adrenergic receptor agonist that has analgesic and antiemetic effects and can be used as an anesthetic adjuvant in cancer surgery. An RCT conducted to evaluate the effect of DEX on perioperative immune function in patients undergoing MT showed that DEX maintains the host immune function, as reflected in the expression of immune cells such as CD4/8 and NK cells, and cytokines such as IL-2, IL-6, and IL-10 (51). Furthermore, a meta-analysis showed that the use of DEX as an adjuvant to anesthetics reduces the use of analgesics such as tramadol, morphine, and fentanyl; prolongs the time to patients' first analgesic request; and relieves postoperative pain (52). The mechanism by which DEX exerts its analgesic effect is unclear, but it may be related to the decreased expression of inflammatory cytokines such as IL-6, TNF- $\alpha$, and Creactive protein (53). Furthermore, DEX administration has been shown to enhance host protective immunity, including increases in NK and CD4+ cells and CD4/CD8 and T helper cell (Th)1/Th2 ratios, via suppression of the HPA axis and SNS stimulation of the surgical stress response in the setting of cancer surgery (53). Despite its anti-inflammatory effects, however, DEX has also been reported to be tumor promoting. It was shown to promote breast cancer cell proliferation, migration, and invasion via activation of the $\alpha 2 \mathrm{~B}$ adrenergic receptor/ERK signaling pathway in vitro and in vivo (54), and to promote the metastasis of breast, lung, and colon cancer cells, mediated by the $\alpha 2$ adrenergic receptor, in animal models (55).

\section{Regional and Intravenous Anesthesia}

RA (e.g., PVB and epidural anesthesia) is expected to suppress neuroendocrine stress responses, reduce the need for opioids, decrease immunosuppression, and induce antitumor and antiinflammatory responses, contributing to the reduction of cancer recurrence, due to the effects of LA on the whole body. Clinical trials suggest that the use of RA and avoidance of opioids is beneficial, but the isolated benefits of abstaining from opioids and adding RA are unclear.
IVA with propofol does not suppress CMI, but it increases cytotoxic T lymphocyte (CTL) activity, decreases inflammatory cytokine levels, and suppresses cyclooxygenase 2 and $\mathrm{PGE}_{2}$ functions $(10,56,57)$. The in-vitro activity of CTLs against EL4 tumor cells was significantly greater after propofol injection than after the injection of vehicle (Intralipid; Nihon Pharmaceutical, Co., Ltd., Osaka, Japan) or saline (10). Propofol also inhibited the growth of EL4 tumors inoculated into mice, suggesting that it has an immune-mediated antitumor effect (10). Propofol and lidocaine reduced lung metastasis, whereas methylprednisolone increased such metastasis, in a mouse model of breast cancer surgery under sevoflurane anesthesia (56).

Propofol maintains the host immune defense via NK cells and innate immunity, and may increase the survival rate of patients with breast cancer more effectively than do inhalational anesthetics (58). Propofol is thought to have antitumor and tumor-promoting effects, depending on its concentration (58). It has been found to inhibit breast tumor invasion and migration by affecting the expression of MMPs, enzymes that play important roles in the degradation of extracellular proteins and EMT (59), via NF- $\mathrm{KB}$ inhibition in vitro (60). In another in-vitro study, propofol inhibited the migration, but not proliferation, of ER-positive and -negative breast cancer cells, mediated by decreased expression of neuroepithelial transforming gene 1, which is associated with enhanced migration (61). In-vitro studies have shown that propofol induces apoptosis in breast cancer cells, by decreasing miR-24 expression and increasing the expression of p27 and cleaved caspase-3 (62), and by increasing the expression of pro-apoptotic proteins such as Bax, Bak, and cytochrome $\mathrm{c}$, followed by the activation of the caspase cascade through an intrinsic apoptotic signaling pathway mediated by reactive oxygen species (63). In addition, propofol was shown in an in-vitro study to suppress HIF-1 activation and downstream genes such as VEGF using macrophage cells, which is expected to inhibit the systemic inflammatory response to surgery (64). In terms of tumor-promoting effects, propofol has been found to increase the migration of breast cancer cells in association with the activation of the $\gamma$-aminobutyric acid type A receptor (65), and to promote the proliferation and migration of human breast cancer cells in association with the inhibition of p53 and activation of nuclear factor E2-related factor-2 in vitro (66). The discrepant effects of propofol on breast cancer may be due to the heterogeneity of this type of cancer; propofol may act differently on different types of cancer cell. In addition, the findings may reflect the lack of standardization of experimental parameters such as the propofol concentration and duration of exposure to cancer cells.

\section{Local Anesthesia}

Clinically relevant concentrations of lidocaine, the most commonly used local anesthetic, enhance NK cell activity in vitro via the release of lytic granules in a variety of human leukemia cells (57). Local anesthetics inhibit the growth of several types of cancer cell, but the mechanism of action is unknown. These anesthetics block voltage-gated sodium channels (67), which are highly expressed in breast cancer and involved in the metastatic process (68). Local anesthetics that 
cause channel blockade inhibit tumor growth. Indeed, lidocaine inhibits tumor cell proliferation and differentiation in vitro, exhibits cytotoxicity against mesenchymal stem cells, and may inhibit tumor growth and metastasis (69). Clinically useful concentrations of lidocaine induced the apoptosis of breast cancer cells in vitro and in vivo, suggesting the usefulness of LA for breast cancer surgery (70). Lidocaine, which inhibits the kinesin motor protein, also decreases the formation and function of tubulin microtentacles in vitro, suggesting that it has a novel ability to inhibit breast cancer metastasis (71). The use of lidocaine at clinical concentrations in vitro causes DNA demethylation as a tumor-suppressive effect on ER-positive and -negative breast cancer cells (72). In addition, lidocaine was shown to inhibit the growth of luminal, TN, and human epidermal growth factor receptor 2 (HER-2)-positive breast cancer cell lines in vitro, the migration of breast tumor epithelial cells relative to normal breast epithelial cells, and the anchorage-independent growth of TN breast cancer cells (73). The intraperitoneal administration of lidocaine improved the survival of mice injected intraperitoneally with $\mathrm{TN}$ breast cancer cells at doses comparable to those used for analgesia in current clinical practice (73). These results suggest that clinically relevant concentrations of lidocaine directly inhibit the growth and metastasis of breast cancer cells. Other studies have shown that the systemic administration of amide local anesthetics inhibits the biological properties of cancer cells $(74,75)$; thus, the systemic administration of lidocaine at the time of tumor resection may inhibit cancer progression. In a mouse model of breast cancer, combination lidocaine and sevoflurane (but not ketamine) anesthesia suppressed lung metastasis, possibly due to the anti-inflammatory and antiangiogenic effects of lidocaine (74). Similarly, in a mouse model of 4T1 breast cancer with surgery performed under sevoflurane anesthesia, the combined administration of cisplatin and lidocaine significantly reduced lung metastasis compared with the control and the administration of cisplatin alone, but did not reduce liver metastasis compared with the control (75). The serum VEGF and IL-6 levels did not differ significantly among these groups, suggesting that lidocaine enhances the metastasis-inhibiting effect of cisplatin under sevoflurane anesthesia (75).

The plasma concentrations of systemically administered lidocaine (as IVA) are significantly higher than those achieved with RA, but not LA. Furthermore, a recent study showed that perioperative lidocaine IVA reduces the postoperative extracellular trapping of neutrophils, an immune and angiogenic factor, and the postoperative expression of MMP-3 in patients undergoing breast cancer surgery, regardless of the GA technique (76). These results suggest that the intravenous administration of lidocaine at the time of breast cancer surgery reduces the risk of postoperative recurrence.

The local anesthetic ropivacaine has a breast cancer-inhibiting effect in vitro due to the disruption of mitochondrial function (77). It inhibited the phosphorylation of Akt, mechanistic target of rapamycin (mTOR), rS6, and ErbB3 binding protein 1 in breast cancer cells, suggesting a link between the Akt/mTOR signaling pathway and mitochondrial function in the context of breast cancer (77). This finding helps us to properly understand the mechanism by which local anesthetics reduce the risk of tumor recurrence. In another study, several local anesthetics (bupivacaine, levobupivacaine, and chloroprocaine) had different in-vitro effects on breast cancer cell survival and migration, suggesting that these effects depend on the exposure time, anesthetic type, and cell line (78).

\section{Muscle Relaxants}

Muscle relaxants are often used for GA. Increases in doses of the chemical reference substances rocuronium bromide and suxamethonium chloride decreased the numbers of normal breast epithelial cells and hormone receptor (HR)-positive breast cancer cells, but not TN breast cancer cells, in vitro (79). Furthermore, rocuronium bromide promoted the invasion, adhesion, and proliferation of TN breast cancer cells, whereas vecuronium bromide had no significant effect on breast cancer cell motility or invasion (79). These findings suggest that certain muscle relaxants affect breast cancer progression.

\section{Mechanical Ventilation}

The use of mechanical ventilation during cancer surgery has been hypothesized to promote lung metastasis; in a mouse model, it altered the interstitial and tissue environments of the lung to favor tumor formation (80). The mechanical ventilation of mice implanted with breast cancer cell lines during MT under GA significantly increased the number of circulating breast cancer cells remaining in the lung microvasculature and the occurrence of postoperative lung metastasis (80). Immunohistochemical analysis showed increased infiltration of CD68-positive macrophages in the injured lung parenchyma and metastatic tumors, and increased expression of epithelial cell adhesion molecules in metastatic nodules (80). Lung metastasis induced by mechanical ventilation occurs via the attraction of circulating tumor cells (CTCs) to the site of lung injury and promotion of the growth of existing lung micrometastases (80). In addition, the paracrine secretion of pro-inflammatory cytokines may induce metastasis to organs other than the lung (81). These observations suggest that the metastasis-promoting effects of mechanical ventilation during breast cancer surgery under GA need to be considered. Non-intubated metastasectomy with video-assisted thoracic surgery induces fewer inflammatory and immune reactions than does conventional surgery with intubation under GA (82). Moreover, with the de-escalation of breast cancer surgery, outpatient procedures can be performed without mechanical ventilation, with the use of lidocaine LA, low-dose propofol IVA, and/or midazolam sedation, which may reduce the recurrence rate; however, this evidence derives from retrospective cohort studies, not studies involving comparison with alternative anesthetic techniques such as standard GA (83, 84). In addition, awake surgery for breast cancer with LA causes less postoperative lymphopenia and may reduce the risk of tumor progression relative to GA (7). Further RCTs comparing total intravenous anesthesia (TIVA) or inhalation anesthesia with mechanical intubation with propofol IVA and/or sedation are needed to clarify the effect of mechanical ventilation on breast cancer recurrence after BCS. 


\section{POSSIBLE MECHANISMS BY WHICH SURGICAL STRESS AND ANESTHESIA- INDUCED IMMUNOSUPPRESSION PROMOTE DISTANT METASTASIS IN PATIENTS WITH BREAST CANCER}

As most breast cancer surgeries can consist of BCS with axillary management (e.g., SLNB or ALND), the impact of surgical stress on immunosuppression can be limited. MT with ALND may cause more surgical stress, leading to immunosuppression, and increase breast cancer recurrence relative to BCS with SLNB. Similarly, the use of inhalation anesthesia and opioids during breast cancer surgery can lead to immunosuppression, increasing recurrence and decreasing survival rates. Decreased host immunity may promote the growth of residual tumor cells in the surgically resected area, dormant tumor cells in other organs, and CTCs after surgery.

Breast cancer is a systemic disease; at the time of initial diagnosis, cells released from the primary tumor are circulating and present as micrometastases (85). In the perioperative period, breast cancer cells may escape surveillance by components of the innate and adaptive immune responses, such as NK cells and CTLs, which promotes distant metastasis via angiogenesis. Tumor dormancy, a quiescent state, is not well understood clinically; it is considered to comprise the lack of angiogenesis and tumor-host immunological equilibrium (86). Under perioperative immunosuppression, dormant cancer (stem) cells may reawaken and regenerate, and they may be detected as clinically visible foci months or years after surgical resection despite adjuvant treatment (86).

Cancer cells produce an immunosuppressive network of tumorderived soluble factors (TDSFs), such as VEGF, which in turn recruit myeloid-derived suppressor cells (MDSCs), which are involved in CMI suppression, from the bone marrow (87). In the tumor microenvironment, immunosuppression due to the use of inhalational anesthesia may suppress the anti-metastatic effects of CMI and allow cancer cells to spread, affecting cancer recurrence and long-term outcomes. Immunosuppression induced by TDSFs can affect residual tumor cells and existing micrometastases and may lead to the formation of new metastatic foci (6).

\section{EFFECT OF ANESTHETICS ON TUMOR ANGIOGENESIS, IMMUNE FUNCTION, INFLAMMATION, AND THE CLINICAL OUTCOMES OF BREAST CANCER SURGERY}

Sevoflurane is thought to promote angiogenesis, whereas propofol inhibits it. Compared with inhalation anesthesia with sevoflurane, TIVA with propofol/remifentanil effectively inhibited the release of VEGF-C induced by breast cancer surgery, but did not significantly affect the 2-year RFS rate, suggesting that it does not affect shortterm breast cancer recurrence (88). Because propofol is less immunosuppressive than inhalation anesthetics, it induces changes in immune cells (e.g., Tregs, Th1 and Th17 cells, NK cells, and CTLs) during breast cancer surgery comparable to those induced by sevoflurane, suggesting that anesthetics have minimal effects on perioperative immune activity (89). The effect of propofol on breast cancer recurrence needs to be investigated further, such as in an RCT comparing the use of RA and TIVA with propofol for anesthesia in breast cancer surgery.

MDSCs are immunosuppressive myeloid cells, and the number of these cells present is related closely to the breast cancer stage, clinical treatment response, and prognosis. Anesthesia with sevoflurane and propofol did not significantly alter the number of MDSCs or the prognosis after breast cancer surgery; compared with BCS, MT with a high degree of surgical stress reduced the number of MDSCs but did not significantly alter the prognosis (90). The postoperative presence of CTCs may be an independent factor influencing long-term outcomes in patients with breast cancer. In an RCT, the type of anesthesia (sevoflurane or propofol) did not affect the number of CTCs present over time after breast cancer surgery, but sevoflurane use significantly increased the maximum number of tumor cells postoperatively (91). In addition, NK cell activity was not associated with the number of CTCs (91).

In another RCT, balanced GA with opioid analgesia increased MOR expression, but not the expression of the immune cell markers CD56, CD57, CD4, and CD68, in resected breast tumors relative to paravertebral-propofol anesthesia (92). Propofol use may be superior to the use of inhalation agents for anesthesia during breast cancer surgery in terms of host defense immunity, but it did not alter the immune response (in terms of NK cells, CTLs, TNF- $\alpha$, IL- 6 , and IL-10) or the apoptosis rate relative to sevoflurane in co-culture with a breast cancer cell line (93).

Inflammation and immunosuppression due to the elevation of the neutrophil-to-lymphocyte ratio (NLR) reflect breast cancer progression and adverse outcomes. In one study, the postoperative (but not preoperative) NLR was lower in the paravertebral propofol group than in the inhalation anesthesia and opioid groups (94), suggesting that paravertebral-propofol anesthesia inhibits the postoperative NLR elevation that may lead to breast cancer recurrence. In addition, NSAIDs may reduce breast cancer recurrence and act on biological mechanisms present in overweight patients. A retrospective study showed that the intraoperative administration of ketorolac was associated with significantly less distant recurrence than was diclofenac administration in patients with high body mass indices undergoing breast cancer surgery (95).

In an RCT, pectoral nerve II block under GA during breast cancer surgery increased the percentage of peripheral NK cells, NK cell-killing activity, and plasma IL-2 level postoperatively relative to GA (96). These results suggest that pectoral nerve II block had a lesser immunosuppressive effect than GA, thereby improving immunity. In another study, propofol-remifentanil anesthesia and postoperative ketorolac analgesia increased NK cell cytotoxicity relative to baseline, whereas sevofluraneremifentanil anesthesia and postoperative fentanyl analgesia decreased this cytotoxicity, adversely affecting immune function, in patients undergoing breast cancer surgery (97). 


\section{RETROSPECTIVE STUDIES}

Thirteen retrospective studies on anesthetic techniques and breast cancer recurrence have been reported (Table 1). Inhalation GA has been compared with RA techniques such as PVB-based GA $(98,99$, 101-103), intravenous propofol-based GA (100, 104, 105, 107110 ), and LA and propofol-based anesthesia (106). In two of these studies, recurrence rates were lower and RFS rates were higher in patients who underwent MT with RA or IV propofol-based GA than in those who underwent the procedure with inhalation-based GA $(98,104)$. In addition, reduced recurrence and increased survival were observed with RA or intravenous propofol-based GA than with inhalation-based GA for BCS and MT in three studies $(99,100,110)$. Propensity score matching with the same variables was used in seven studies, of which one showed a potential benefit of propofol anesthesia (110). These findings suggest that RA and intravenous propofol-based GA reduce breast cancer recurrence compared with inhalation GA. However, the sample size and follow-up period were insufficient to assess breast cancer recurrence in some of the studies.

Two meta-analyses including data on breast cancer and other cancers have been reported (Table 2). One meta-analysis showed no OS or RFS benefit of GA/RA over inhalation GA for gastrointestinal, prostate, breast, and ovarian cancer surgeries (111). The other metaanalysis showed that propofol-based TIVA for breast, esophageal, and non-small cell lung cancer surgeries (thus not breast cancer surgery alone) was associated with improved OS and RFS relative to inhalation anesthesia (112). Thus, intravenous propofol-based GA, but not GA/RA, may reduce breast cancer recurrence and increase survival compared with inhalation GA.

\section{PROSPECTIVE STUDIES}

Two prospective RCTs examining anesthetic techniques and breast cancer recurrence have been reported (Table 3 ). In the

TABLE 1 | Retrospective analyses of anesthetic technique and breast cancer recurrence.

\begin{tabular}{|c|c|c|c|c|c|}
\hline $\begin{array}{l}\text { Ref. } \\
\text { (year) }\end{array}$ & $\begin{array}{l}\text { Cancer type } \\
\text { (patient } n \text { ) }\end{array}$ & Surgery type & Anesthetic technique & Outcomes & $\begin{array}{l}\text { Benefit/ } \\
\text { remarks }\end{array}$ \\
\hline $\begin{array}{l}98 \\
(2006)\end{array}$ & $\begin{array}{l}\text { Stage } 1-\text { III breast } \\
(n=129)\end{array}$ & $\begin{array}{l}\text { Mastectomy and } \\
\text { axillary clearance }\end{array}$ & $\begin{array}{l}\text { GA/PVA }(n=50) \text { vs. GA/opioid } \\
\text { anesthesia }(n=79)\end{array}$ & $\begin{array}{l}\text { 4-fold reduced recurrence or metastasis risk during } \\
2.5 \text { to } 4 \text {-year follow-up period with GA/PVA } \\
\text { Increased RFS at } 3 \text { years with GA/PVA ( } 94 \% \text { vs. } 77 \% \text { ) }\end{array}$ & Positive \\
\hline $\begin{array}{l}99 \\
(2014)\end{array}$ & $\begin{array}{l}\text { Stage } 0-11 \text { breast } \\
(n=619)\end{array}$ & $\begin{array}{l}\text { Breast-conserving } \\
\text { surgery or total } \\
\text { mastectomy }\end{array}$ & $\begin{array}{l}\text { RA }(n=123) \text { vs. RA/GA }(n=90) \text { vs. GA } \\
(n=406)\end{array}$ & $\begin{array}{l}\text { Trend of reduced recurrence with RA, with or without } \\
\text { GA }\end{array}$ & $\begin{array}{l}\text { Potential } \\
\text { benefit }\end{array}$ \\
\hline $\begin{array}{l}100 \\
(2014)\end{array}$ & $\begin{array}{l}\text { Breast, colon, } \\
\text { rectal }(n=2838)\end{array}$ & Radical cancer surgery & $\begin{array}{l}\text { Propofol }(n=902) \text { vs. sevoflurane } \\
(n=1935)\end{array}$ & Favorable 1- and 5-year OS rates with propofol & $\begin{array}{l}\text { Potential } \\
\text { benefit }\end{array}$ \\
\hline $\begin{array}{l}101 \\
(2015)\end{array}$ & $\begin{array}{l}\text { Stage 0-III breast } \\
(n=358)\end{array}$ & $\begin{array}{l}\text { Partial or total } \\
\text { mastectomy without } \\
\text { axillary node dissection }\end{array}$ & GA/PVA $(n=193)$ vs. GA $(n=165)$ & No difference in recurrence & Negative \\
\hline $\begin{array}{l}102 \\
(2016)\end{array}$ & $\begin{array}{l}\text { Stage } 0-11 \text { breast } \\
(n=1107)\end{array}$ & $\begin{array}{l}\text { Mastectomy or breast- } \\
\text { conserving surgery }\end{array}$ & $\begin{array}{l}\text { LRA }(n=646) \text { vs. GA }(n=461) ; \text { PSM } \\
(n=375 \text { each })\end{array}$ & No difference in OS, DFS, or LRR & Negative/PSM \\
\hline $\begin{array}{l}103 \\
(2016)\end{array}$ & $\begin{array}{l}\text { Stage I-III breast } \\
(n=792)\end{array}$ & $\begin{array}{l}\text { Mastectomy with or } \\
\text { without axillary node } \\
\text { dissection }\end{array}$ & $\begin{array}{l}\text { PVB }(n=198) \text { vs. opioid-based } \\
\text { analgesia } \\
(n=594) ; \text { PSM ( } n=197 \text { each })\end{array}$ & No difference in RFS or OS & Negative/PSM \\
\hline $\begin{array}{l}104 \\
(2016)\end{array}$ & $\begin{array}{l}\text { Stage } 1-|I| \text { breast } \\
(n=325)\end{array}$ & $\begin{array}{l}\text { Modified radical } \\
\text { mastectomy }\end{array}$ & $\begin{array}{l}\text { Propofol TIVA }(n=173) \text { vs. sevoflurane } \\
(n=152)\end{array}$ & Less recurrence over 5 years with propofol & Positive \\
\hline $\begin{array}{l}105 \\
(2017)\end{array}$ & $\begin{array}{l}\text { Stage I-III breast } \\
(n=2645)\end{array}$ & $\begin{array}{l}\text { Breast-conserving } \\
\text { surgery or mastectomy }\end{array}$ & $\begin{array}{l}\text { Propofol TIVA ( } n=56) \text { vs. inhalation } \\
\text { anesthesia }(n=2589) \text { : PSM ( } 1: 5 \\
\text { matching for each inhalation agent) }\end{array}$ & No difference in RFS or OS & Negative/PSM \\
\hline $\begin{array}{l}106 \\
(2017)\end{array}$ & $\begin{array}{l}\text { Stage I-II breast } \\
(n=91, \text { elderly })\end{array}$ & $\begin{array}{l}\text { Breast-conserving } \\
\text { surgery with SLNB or } \\
\text { axillary dissection }\end{array}$ & $\begin{array}{l}\text { LA/midazolam/remifentanil/propofol } \\
(n=37) \text { vs. GA }(n=54)\end{array}$ & No difference in locoregional RFS or OS & Negative \\
\hline $\begin{array}{l}107 \\
(2019)\end{array}$ & $\begin{array}{l}\text { Stage 0-III breast } \\
(n=976)\end{array}$ & Breast cancer surgery & $\begin{array}{l}\text { Propofol }(n=344) \text { vs. desflurane } \\
(n=632) ; \operatorname{PSM}(n=296,592)\end{array}$ & No difference in LRR or 5-year OS & Negative/PSM \\
\hline $\begin{array}{l}108 \\
(2019)\end{array}$ & $\begin{array}{l}\text { Stage } 0-11 \text { l breast } \\
(n=5331)\end{array}$ & $\begin{array}{l}\text { Breast-conserving } \\
\text { surgery or total } \\
\text { mastectomy }\end{array}$ & $\begin{array}{l}\text { Propofol TIVA }(n=3085) \text { vs. inhalation } \\
\text { anesthesia }(n=2246) ; \text { PSM }(n=1766 \\
\text { each) }\end{array}$ & No difference in 5-year RFS or OS & Negative/PSM \\
\hline $\begin{array}{l}109 \\
(2020)\end{array}$ & $\begin{array}{l}\text { Stage } 0-\text { III breast } \\
(n=1026)\end{array}$ & Mastectomy & $\begin{array}{l}\text { Propofol TIVA }(n=814) \text { vs. sevoflurane } \\
(n=212) ; \text { PSM } \\
(n=159 \text { each })\end{array}$ & $\begin{array}{l}\text { No difference in 1-year RFS } \\
\text { HR for recurrence or metastasis after sevoflurane vs. } \\
\text { propofol was significantly higher for luminal B HER-2 } \\
\text { (+) subtype than for other subtypes }\end{array}$ & Negative/PSM \\
\hline $\begin{array}{l}110 \\
(2020)\end{array}$ & $\begin{array}{l}\text { Stage 0-IV breast } \\
(n=6305)\end{array}$ & $\begin{array}{l}\text { Total or partial } \\
\text { mastectomy, with or } \\
\text { without axillary } \\
\text { clearance }\end{array}$ & $\begin{array}{l}\text { Propofol }(n=3296) \text { vs. sevoflurane } \\
(n=3209)\end{array}$ & Trend toward better 5-year OS with propofol & $\begin{array}{l}\text { Potential } \\
\text { benefit/PSM }\end{array}$ \\
\hline
\end{tabular}

GA, general anesthesia; PVA, paravertebral anesthesia; RFS, recurrence-free survival; RA, regional anesthesia; OS, overall survival; LRA, local or regional anesthesia; PSM, propensity score-matched analysis; DFS, disease-free survival; LRR, locoregional recurrence; PVB, paravertebral block; TIVA, total intravenous anesthesia; SLNB, sentinel lymph-node biopsy; LA, local anesthesia; HR, hazard ratio; HER-2, human epidermal growth factor receptor 2. 
TABLE 2 | Meta-analyses of anesthetic technique and breast cancer recurrence.

\begin{tabular}{|c|c|c|c|c|c|}
\hline $\begin{array}{l}\text { Ref. } \\
\text { (year) }\end{array}$ & Cancer type (patient $n$ ) & Surgery type & Anesthetic technique & Outcomes & $\begin{array}{l}\text { Benefit/ } \\
\text { remarks }\end{array}$ \\
\hline $\begin{array}{l}111 \\
(2017)\end{array}$ & $\begin{array}{l}\text { Gastrointestinal, breast, prostate, ovarian } \\
(n=67,577)\end{array}$ & Cancer surgery & $\begin{array}{l}\text { RA/inhalation anesthesia vs. } \\
\text { inhalation anesthesia }\end{array}$ & $\begin{array}{l}\text { No difference in OS, RFS, or BRFS } \\
\text { Some benefit of OS in RCT on } \\
\text { colorectal cancer }\end{array}$ & Negative \\
\hline $\begin{array}{l}112 \\
(2019)\end{array}$ & $\begin{array}{l}\text { Breast, esophageal, NSLC }(n=7866) \\
\text { Breast, colorectal, gastric, esophageal, NSLC, } \\
\text { mixed }(n=18,778)\end{array}$ & $\begin{array}{l}\text { Radical cancer } \\
\text { surgery }\end{array}$ & $\begin{array}{l}\text { Propofol TIVA vs. inhalation } \\
\text { anesthesia }\end{array}$ & $\begin{array}{l}\text { Improved RFS with TIVA } \\
\text { Improved OS with TIVA }\end{array}$ & Positive \\
\hline
\end{tabular}

RCT, randomized controlled trial; NSLC, non-small cell lung cancer; BRFS, biochemical recurrence-free survival.

first trial, the use of standardized GA alone, GA plus singleinjection thoracic paravertebral block (TPVB), and GA plus TPVB for 72 continuous hours was compared in a total of 180 patients with breast cancer undergoing modified radical MT (113). Neither TPVB technique had a major effect on postoperative local recurrence, metastasis, or 5-year mortality (113). The sample size and follow-up period in that study were insufficient for comprehensive evaluation of the effect of PVB on breast cancer recurrence. In the second RCT, breast cancer recurrence at a median of 36 months did not differ according to the use of PVB/propofol-based GA or sevoflurane/opioidbased GA in a total of 2108 patients who underwent surgery for breast cancer (114). That study was designed based on a retrospective report that GA/PVB reduced breast cancer recurrence at 3 years postoperatively by about one-fourth compared with GA/opioid use in patients who underwent MT with ALND (98), but it did not yield the same results. Several factors may explain this discrepancy. First, there was a large overlap in the use of propofol, sevoflurane, and opioids in both groups in the prospective study. Second, patients in that study did not undergo MT, and more than $30 \%$ of BCSs included were performed in China. Third, the median follow-up period was insufficient, as $>50 \%$ of HR-positive breast cancers recur at $>5$ years postoperatively. Fourth, the frequency of breast cancer recurrence depends on the tumor subtype; TN and HER-2positive breast cancers are more likely to recur than are HRpositive breast cancers. However, the randomization variables used in the prospective study pertain only to ER status. These factors may have led to bias and prevent the drawing of an accurate conclusion regarding the effect of PVB on breast cancer recurrence.

Three prospective RCTs (one completed and two ongoing) have been designed to investigate the relationship between anesthesia technique and breast cancer recurrence. A pilot trial
(NCT01975064) examined the effects of propofol IVA and sevoflurane anesthesia on survival after radical surgery in patients with breast, colorectal, prostate, melanoma, lung, and other cancers; of 217 eligible patients, 146 were recruited (67.3\% recruitment rate), supporting the performance of a large RCT to determine the effect of anesthetic technique on cancer recurrence (115). In the second trial (NCT04074460), the efficacy of propofol IVA and inhalation anesthetics such as sevoflurane, isoflurane, and desflurane is being compared in terms of recruitment $(75 \%)$ and anesthesia administration $(90 \%)$ success rates among eligible patients with breast, colorectal, prostate, lung, melanoma, and other cancers. In the third trial (NCT01916317), the effects of the perioperative injection of lidocaine in the setting of breast cancer are being examined as part of the assessment of the in-vivo ability of local anesthetics to reduce the dissemination of cancer cells during surgery and improve the disease-free interval (i.e., affect tumor recurrence). Future RCTs must be designed with consideration of the breast cancer surgery type and use of mechanical ventilation, as the use of less-immunosuppressive anesthesia and non-mechanical ventilation may best reduce breast cancer recurrence. For patients who have undergone MT with SLNB or ALND, the effects of propofol IVA with RA and inhalation anesthesia with opioids could be compared. For patients who have undergone BCS with SLNB, the effects of mechanical and non-mechanical ventilation could be compared.

\section{CONCLUDING REMARKS}

At this time, RCTs have not provided sufficient evidence that the anesthetic technique is associated with the recurrence rate or long-term outcomes in patients undergoing breast cancer surgery. Preclinical and clinical studies have provided

TABLE 3 | Prospective randomized trials on anesthetic technique and breast cancer recurrence.

\begin{tabular}{|c|c|c|c|c|c|}
\hline $\begin{array}{l}\text { Ref. } \\
\text { (year) }\end{array}$ & $\begin{array}{l}\text { Cancer type } \\
\text { (patient } n \text { ) }\end{array}$ & Surgery type & Anesthetic technique & Outcomes & $\begin{array}{l}\text { Benefit/ } \\
\text { remarks }\end{array}$ \\
\hline $\begin{array}{l}113 \\
(2017)\end{array}$ & $\begin{array}{l}\text { Stage I-IV breast } \\
(n=180)\end{array}$ & $\begin{array}{l}\text { Modified radical } \\
\text { mastectomy }\end{array}$ & $\begin{array}{l}\text { GA }(n=58) \text { vs. GA with single-injection TPVB }(n=56) \text { vs. GA } \\
\text { with continuous TPVB for } 72 \text { h postoperatively }(n=59)\end{array}$ & $\begin{array}{l}\text { Little to no effect of TPVB on local } \\
\text { recurrence, metastasis, or mortality at } \\
5 \text { years }\end{array}$ & Negative \\
\hline $\begin{array}{l}114 \\
(2019)\end{array}$ & $\begin{array}{l}\text { Stage 0-III breast } \\
(n=2132)\end{array}$ & $\begin{array}{l}\text { Breast cancer } \\
\text { surgery }\end{array}$ & RA/propofol $(n=1043)$ vs. sevoflurane/opioids $(n=1065)$ & $\begin{array}{l}\text { No difference in recurrence at a median of } \\
36 \text { months }\end{array}$ & Negative \\
\hline
\end{tabular}

TPVB, thoracic paravertebral block. 
conflicting data on the effects of inhalation anesthetics, propofol, and opioids on the immune response and breast cancer growth. However, RA (e.g., PVB or propofol IVA), LA, and/or nonmechanical ventilation with non-opioid anesthesia may reduce breast cancer recurrence compared with intravenous or inhalation GA, opioid use, and/or mechanical ventilation. As most current breast cancer surgeries, especially BCS, are performed with IVA, the superiority of this technique to inhalation anesthesia may be difficult to evaluate. Nevertheless, such efforts are being made in ongoing RCTs, and we await their results for breast cancer and other cancers. Further such trials are

\section{REFERENCES}

1. Kim R. Anesthetic Technique and Cancer Recurrence in Oncologic Surgery: Unraveling the Puzzle. Cancer Metastasis Rev (2017) 36:159-77. doi: 10.1007/ s10555-016-9647-8

2. Schlagenhauff B, Ellwanger U, Breuninger H, Stroebel W, Rassner G, Garbe C. Prognostic Impact of the Type of Anaesthesia Used During the Excision of Primary Cutaneous Melanoma. Melanoma Res (2000) 10:165-9. doi: 10.1097/00008390-200004000-00009

3. Stollings LM, Jia LJ, Tang P, Dou H, Lu B, Xu Y. Immune Modulation by Volatile Anesthetics. Anesthesiology (2016) 125:399-411. doi: 10.1097/ ALN.0000000000001195

4. Melamed R, Bar-Yosef S, Shakhar G, Shakhar K, Ben-Eliyahu S. Suppression of Natural Killer Cell Activity and Promotion of Tumor Metastasis by Ketamine, Thiopental, and Halothane, But Not by Propofol: Mediating Mechanisms and Prophylactic Measures. Anesth Analg (2003) 97:1331-9. doi: 10.1213/01.ane.0000082995.44040.07

5. Loop T, Dovi-Akue D, Frick M, Roesslein M, Egger L, Humar M, et al. Volatile Anesthetics Induce Caspase-Dependent, Mitochondria-Mediated Apoptosis in Human T Lymphocytes In Vitro. Anesthesiology (2005) 102:1147-57. doi: 10.1097/00000542-200506000-00014

6. Kim R. Effects of Surgery and Anesthetic Choice on Immunosuppression and Cancer Recurrence. J Transl Med (2018) 16:8. doi: 10.1186/s12967-0181389-7

7. Vanni G, Materazzo M, Perretta T, Meucci R, Anemona L, Buonomo C, et al. Impact of Awake Breast Cancer Surgery on Postoperative Lymphocyte Responses. In Vivo (2019) 33:1879-84. doi: 10.21873/invivo.11681

8. Tang F, Tie Y, Tu C, Wei X. Surgical Trauma-Induced Immunosuppression in Cancer: Recent Advances and the Potential Therapies. Clin Transl Med (2020) 10:199-223. doi: $10.1002 / \mathrm{ctm} 2.24$

9. Yardeni IZ, Beilin B, Mayburd E, Alcalay Y, Bessler H. Relationship Between Fentanyl Dosage and Immune Function in the Postoperative Period. J Opioid Manag (2008) 4:27-33. doi: 10.5055/jom.2008.0005

10. Kushida A, Inada T, Shingu K. Enhancement of Antitumor Immunity After Propofol Treatment in Mice. Immunopharmacol Immunotoxicol (2007) 29:477-86. doi: 10.1080/08923970701675085

11. Xuan W, Hankin J, Zhao H, Yao S, Ma D. The Potential Benefits of the Use of Regional Anesthesia in Cancer Patients. Int J Cancer (2015) 137:2774-84. doi: $10.1002 /$ ijc. 29306

12. Mao L, Lin S, Lin J. The Effects of Anesthetics on Tumor Progression. Int J Physiol Pathophysiol Pharmacol (2013) 5:1-10.

13. Looney M, Doran P, Buggy DJ. Effect of Anesthetic Technique on Serum Vascular Endothelial Growth Factor C and Transforming Growth Factor $\beta$ in Women Undergoing Anesthesia and Surgery for Breast Cancer. Anesthesiology (2010) 113:1118-25. doi: 10.1097/ALN.0b013e3181f79a69

14. Baum M, Demicheli R, Hrushesky W, Retsky M. Does Surgery Unfavourably Perturb the "Natural History" of Early Breast Cancer by Accelerating the Appearance of Distant Metastases? Eur J Cancer (2005) 41:508-15. doi: 10.1016/j.ejca.2004.09.031

15. Retsky M, Demicheli R, Hrushesky WJ. Does Surgery Induce Angiogenesis in Breast Cancer? Indirect Evidence From Relapse Pattern and needed for the development of systemic breast cancer therapies, which will bring us closer to a cure for primary breast cancer.

\section{AUTHOR CONTRIBUTIONS}

Conceptualization, RK. Resources, RK. Writing-original draft preparation, RK. Writing-review and editing, RK, AK, MW, and TK. All authors contributed to the article and approved it for publication.
Mammography Paradox. Int J Surg (2005) 3:179-87. doi: 10.1016/j.ijsu. 2005.08.002

16. Hwang ES, Lichtensztajn DY, Gomez SL, Fowble B, Clarke CA. Survival After Lumpectomy and Mastectomy for Early Stage Invasive Breast Cancer: The Effect of Age and Hormone Receptor Status. Cancer (2013) 119:140211. doi: $10.1002 /$ cncr.27795

17. Hofvind S, Holen A, Aas T, Roman M, Sebuødegård S, Akslen LA. Women Treated With Breast Conserving Surgery Do Better Than Those With Mastectomy Independent of Detection Mode, Prognostic and Predictive Tumor Characteristics. Eu J Surg Oncol (2015) 41:1417-22. doi: 10.1016/ j.ejso.2015.07.002

18. de Boniface J, Szulkin R, Johansson ALV. Survival After Breast Conservation vs Mastectomy Adjusted for Comorbidity and Socioeconomic Status: A Swedish National 6-Year Follow-Up of 48986 Women. JAMA Surg (2021) 156:628-37. doi: 10.1001/jamasurg.2021.1438

19. Zhao T, Xia WH, Zheng MQ, Lu CQ, Han X, Sun YJ. Surgical Excision Promotes Tumor Growth and Metastasis by Promoting Expression of MMP-9 and VEGF in a Breast Cancer Model. Exp Oncol (2008) 30:60-4.

20. Padua D, Zhang XH, Wang Q, Nadal C, Gerald WL, Gomis RR, et al. TGFbeta Primes Breast Tumors for Lung Metastasis Seeding Through Angiopoietin-Like 4. Cell (2008) 133:66-77. doi: 10.1016/j.cell.2008.01.046

21. Demicheli R, Miceli R, Moliterni A, Zambetti M, Hrushesky WJ, Retsky MW, et al. Breast Cancer Recurrence Dynamics Following Adjuvant CMF Is Consistent With Tumor Dormancy and Mastectomy-Driven Acceleration of the Metastatic Process. Ann Oncol (2005) 16:1449-57. doi: 10.1093/annonc/ mdi280

22. Tavare AN, Perry NJ, Benzonana LL, Takata M, Ma D. Cancer Recurrence After Surgery: Direct and Indirect Effects of Anesthetic Agents. Int $J$ Cancer (2012) 130:1237-50. doi: 10.1002/ijc.26448

23. Deegan CA, Murray D, Doran P, Moriarty DC, Sessler DI, Mascha E, et al. Anesthetic Technique and the Cytokine and Matrix Metalloproteinase Response to Primary Breast Cancer Surgery. Reg Anesth Pain Med (2010) 35:490-5. doi: 10.1097/AAP.0b013e3181ef4d05

24. Ecimovic P, McHugh B, Murray D, Doran P, Buggy DJ. Effects of Sevoflurane on Breast Cancer Cell Function. vitro Anticancer Res (2013) 33:4255-60.

25. Deegan CA, Murray D, Doran P, Ecimovic P, Moriarty DC, Buggy DJ. Effect of Anaesthetic Technique on Oestrogen Receptor-Negative Breast Cancer Cell Function In Vitro. Br J Anaesth (2009) 103:685-90. doi: 10.1093/bja/ aep261

26. Wu T, Sun L, Wang C, Yu P, Cheng L, Chen Y. Sevoflurane Suppresses the Migration, Invasion, and Epithelial-Mesenchymal Transition of Breast Cancer Cells Through the miR-139-5p/ARF6 Axis. J Surg Res (2021) 258:314-23. doi: 10.1016/j.jss.2020.08.051

27. Krishnan K, Steptoe AL, Martin HC, Pattabiraman DR, Nones K, Waddell $\mathrm{N}$, et al. miR-139-5p Is a Regulator of Metastatic Pathways in Breast Cancer. RNA (2013) 19:1767-80. doi: 10.1261/rna.042143.113

28. Hongu T, Funakoshi Y, Fukuhara S, Suzuki T, Sakimoto S, Takakura N, et al. Arf6 Regulates Tumour Angiogenesis and Growth Through HGF-Induced Endothelial $\beta 1$ Integrin Recycling. Nat Commun (2015) 6:7925. doi: 10.1038/ ncomms 8925 
29. Sacerdote P, Bianchi M, Gaspani L, Manfredi B, Maucione A, Terno G, et al. The Effects of Tramadol and Morphine on Immune Responses and Pain After Surgery in Cancer Patients. Anesth Analg (2000) 90:1411-4. doi: 10.1097/00000539-200006000-00028

30. Gao M, Sun J, Jin W, Qian Y. Morphine, But Not Ketamine, Decreases the Ratio of Th1/Th2 in CD4-Positive Cells Through T-Bet and GATA3. Inflammation (2012) 35:1069-77. doi: 10.1007/s10753-011-9413-6

31. Franchi S, Moretti S, Castelli M, Lattuada D, Scavullo C, Panerai AE, et al. Mu Opioid Receptor Activation Modulates Toll Like Receptor 4 in Murine Macrophages. Brain Behav Immun (2012) 26:480-8. doi: 10.1016/ j.bbi.2011.12.010

32. Das J, Kumar S, Khanna S, Mehta Y. Are We Causing the RecurrenceImpact of Perioperative Period on Long-Term Cancer Prognosis: Review of Current Evidence and Practice. J Anaesthesiol Clin Pharmacol (2014) 30:153-9. doi: 10.4103/0970-9185.129996

33. Shavit Y, Ben-Eliyahu S, Zeidel A, Beilin B. Effects of Fentanyl on Natural Killer Cell Activity and on Resistance to Tumor Metastasis in Rats. Dose and Timing Study. Neuroimmunomodulation (2004) 11:255-60. doi: 10.1159/ 000078444

34. Gong L, Qin Q, Zhou L, Ouyang W, Li Y, Wu Y, et al. Effects of Fentanyl Anesthesia and Sufentanil Anesthesia on Regulatory T Cells Frequencies. Int J Clin Exp Pathol (2014) 7:7708-16.

35. Sacerdote P, Gaspani L, Rossoni G, Panerai AE, Bianchi M. Effect of the Opioid Remifentanil on Cellular Immune Response in the Rat. Int Immunopharmacol (2001) 1:713-9. doi: 10.1016/s1567-5769(01)00005-4

36. Hatzoglou A, Bakogeorgou E, Castanas E. The Antiproliferative Effect of Opioid Receptor Agonists on the T47D Human Breast Cancer Cell Line, Is Partially Mediated Through Opioid Receptors. Eur J Pharmacol (1996) 296:199-207. doi: 10.1016/0014-2999(95)00703-2

37. Singhal PC, Sharma P, Kapasi AA, Reddy K, Franki N, Gibbons N. Morphine Enhances Macrophage Apoptosis. J Immunol (1998) 160:188693.

38. Gupta K, Kshirsagar S, Chang L, Schwartz R, Law PY, Yee D, et al. Morphine Stimulates Angiogenesis by Activating Proangiogenic and SurvivalPromoting Signaling and Promotes Breast Tumor Growth. Cancer Res (2002) 62:4491-8.

39. Tegeder I, Geisslinger G. Opioids as Modulators of Cell Death and SurvivalUnraveling Mechanisms and Revealing New Indications. Pharmacol Rev (2004) 56:351-69. doi: 10.1124/pr.56.3.2

40. Singleton PA, Mirzapoiazova T, Hasina R, Salgia R, Moss J. Increased $\mu-$ Opioid Receptor Expression in Metastatic Lung Cancer. Br J Anaesth (2014) 113 Suppl 1:103-8. doi: 10.1093/bja/aeu165

41. Cheng S, Guo M, Liu Z, Fu Y, Wu H, Wang C, et al. Morphine Promotes the Angiogenesis of Postoperative Recurrent Tumors and Metastasis of Dormant Breast Cancer Cells. Pharmacology (2019) 104:276-86. doi: 10.1159/ 000502107

42. Liu Z, Cheng S, Fu G, Ji F, Wang C, Cao M. Postoperative Administration of Ketorolac Averts Morphine-Induced Angiogenesis and Metastasis in TripleNegative Breast Cancer. Life Sci (2020) 251:117604. doi: 10.1016/ j.lfs.2020.117604

43. Lin X, Wang YJ, Li Q, Hou YY, Hong MH, Cao YL, et al. Chronic High-Dose Morphine Treatment Promotes SH-SY5Y Cell Apoptosis via C-Jun NTerminal Kinase-Mediated Activation of Mitochondria-Dependent Pathway. FEBS J (2009) 276:2022-36. doi: 10.1111/j.1742-4658.2009.06938.x

44. Bimonte S, Barbieri A, Rea D, Palma G, Luciano A, Cuomo A, et al. Morphine Promotes Tumor Angiogenesis and Increases Breast Cancer Progression. BioMed Res Int (2015) 2015:161508. doi: 10.1155/2015/161508

45. Leo S, Nuydens R, Meert TF. Opioid-Induced Proliferation of Vascular Endothelial Cells. J Pain Res (2009) 2:59-66. doi: 10.2147/jpr.s4748

46. Page GG, Ben-Eliyahu S, Yirmiya R, Liebeskind JC. Morphine Attenuates Surgery-Induced Enhancement of Metastatic Colonization in Rats. Pain (1993) 54:21-8. doi: 10.1016/0304-3959(93)90095-7

47. Page GG, McDonald JS, Ben-Eliyahu S. Pre-Operative Versus Postoperative Administration of Morphine: Impact on the Neuroendocrine, Behavioural, and Metastatic-Enhancing Effects of Surgery. Br J Anaesth (1998) 81:216-23. doi: $10.1093 / \mathrm{bja} / 81.2 .216$

48. Montagna G, Gupta HV, Hannum M, Tan KS, Lee J, Scarpa JR, et al. Intraoperative Opioids Are Associated With Improved Recurrence-Free
Survival in Triple-Negative Breast Cancer. Br J Anaesth (2021) 126:36776. doi: 10.1016/j.bja.2020.10.021

49. Kim MH, Oh JE, Park S, Kim JH, Lee KY, Bai SJ, et al. Tramadol Use Is Associated With Enhanced Postoperative Outcomes in Breast Cancer Patients: A Retrospective Clinical Study With In Vitro Confirmation. Br J Anaesth (2019) 123:865-76. doi: 10.1016/j.bja.2019.09.004

50. Kim MH, Yoo JH, Cho HJ, Ko KJ, Jun KW, Han KD, et al. Identification for Antitumor Effects of Tramadol in a Xenograft Mouse Model Using Orthotopic Breast Cancer Cells. Ann Surg Treat Res (2021) 101:291-8. doi: 10.4174/astr.2021.101.5.291

51. Yang XH, Bai Q, Lv MM, Fu HG, Dong TL, Zhou Z. Effect of Dexmedetomidine on Immune Function of Patients Undergoing Radical Mastectomy: A Double Blind and Placebo Control Study. Eur Rev Med Pharmacol Sci (2017) 21:1112-6.

52. Liu C, Wang W, Shan Z, Zhang H, Yan Q. Dexmedetomidine as an Adjuvant for Patients Undergoing Breast Cancer Surgery: A Meta-Analysis. Med (Baltimore) (2020) 99:e23667. doi: 10.1097/MD.0000000000023667

53. Wang K, Wu M, Xu J, Wu C, Zhang B, Wang G, et al. Effects of Dexmedetomidine on Perioperative Stress, Inflammation, and Immune Function: Systematic Review and Meta-Analysis. Br J Anaesth (2019) 123:777-94. doi: 10.1016/j.bja.2019.07.027

54. Xia M, Ji NN, Duan ML, Tong JH, Xu JG, Zhang YM, et al. Dexmedetomidine Regulate the Malignancy of Breast Cancer Cells by Activating $\alpha 2$-Adrenoceptor/ERK Signaling Pathway. Eur Rev Med Pharmacol Sci (2016) 20:3500-6.

55. Lavon H, Matzner P, Benbenishty A, Sorski L, Rossene E, Haldar R, et al. Dexmedetomidine Promotes Metastasis in Rodent Models of Breast, Lung, and Colon Cancers. Br J Anaesth (2018) 120:188-96. doi: 10.1016/j.bja.2017.11.004

56. Freeman J, Crowley PD, Foley AG, Gallagher HC, Iwasaki M, Ma D, et al. Effect of Perioperative Lidocaine, Propofol and Steroids on Pulmonary Metastasis in a Murine Model of Breast Cancer Surgery. Cancers (Basel) (2019) 11:613. doi: 10.3390/cancers11050613

57. Ramirez MF, Tran P, Cata JP. The Effect of Clinically Therapeutic Plasma Concentrations of Lidocaine on Natural Killer Cell Cytotoxicity. Reg Anesth Pain Med (2015) 40:43-8. doi: 10.1097/AAP.0000000000000191

58. Li R, Liu H, Dilger JP, Lin J. Effect of Propofol on Breast Cancer Cell, the Immune System, and Patient Outcome. BMC Anesthesiol (2018) 18:77. doi: 10.1186/s12871-018-0543-3

59. Gialeli C, Theocharis AD, Karamanos NK. Roles of Matrix Metalloproteinases in Cancer Progression and Their Pharmacological Targeting. FEBS J (2011) 278:16-27. doi: 10.1111/j.1742-4658.2010.07919.x

60. Li Q, Zhang L, Han Y, Jiang Z, Wang Q. Propofol Reduces MMPs Expression by Inhibiting NF- $\mathrm{kb}$ Activity in Human MDA-MB-231 Cells. BioMed Pharmacother (2012) 66:52-6. doi: 10.1016/j.biopha.2011.10.006

61. Ecimovic P, Murray D, Doran P, Buggy DJ. Propofol and Bupivacaine in Breast Cancer Cell Function In Vitro - Role of the NET1 Gene. Anticancer Res (2014) 34:1321-31.

62. Yu B, Gao W, Zhou H, Miao X, Chang Y, Wang L, et al. Propofol Induces Apoptosis of Breast Cancer Cells by Downregulation of miR-24 Signal Pathway. Cancer Biomark (2018) 21:513-9. doi: 10.3233/CBM-170234

63. Wang H, Zhao L, Wu J, Hong J, Wang S. Propofol Induces ROS-Mediated Intrinsic Apoptosis and Migration in Triple-Negative Breast Cancer Cells. Oncol Lett (2020) 20:810-6. doi: 10.3892/ol.2020.11608

64. Tanaka T, Takabuchi S, Nishi K, Oda S, Wakamatsu T, Daijo H, et al. The Intravenous Anesthetic Propofol Inhibits Lipopolysaccharide-Induced Hypoxia-Inducible Factor 1 Activation and Suppresses the Glucose Metabolism in Macrophages. J Anesth (2010) 24:54-60. doi: 10.1007/ s00540-009-0829-1

65. Garib V, Lang K, Niggemann B, Zänker KS, Brandt L, Dittmar T. PropofolInduced Calcium Signalling and Actin Reorganization Within Breast Carcinoma Cells. Eur J Anaesthesiol (2005) 22:609-15. doi: 10.1017/ s026502150500102x

66. Meng C, Song L, Wang J, Li D, Liu Y, Cui X. Propofol Induces Proliferation Partially via Downregulation of P53 Protein and Promotes Migration via Activation of the Nrf2 Pathway in Human Breast Cancer Cell Line MDAMB-231. Oncol Rep (2017) 37:841-8. doi: 10.3892/or.2016.5332

67. Baptista-Hon DT, Robertson FM, Robertson GB, Owen SJ, Rogers GW, Lydon EL, et al. Potent Inhibition by Ropivacaine of Metastatic Colon 
Cancer SW620 Cell Invasion and NaV1.5 Channel Function. Br J Anaesth (2014) 113 Suppl 1:i39-48. doi: 10.1093/bja/aeu104

68. Fraser SP, Diss JK, Chioni AM, Mycielska ME, Pan H, Yamaci RF, et al. Voltage-Gated Sodium Channel Expression and Potentiation of Human Breast Cancer Metastasis. Clin Cancer Res (2005) 11:5381-9. doi: 10.1158/ 1078-0432.CCR-05-0327

69. Lucchinetti E, Awad AE, Rahman M, Feng J, Lou PH, Zhang L, et al. Antiproliferative Effects of Local Anesthetics on Mesenchymal Stem Cells: Potential Implications for Tumor Spreading and Wound Healing. Anesthesiology (2012) 116:841-56. doi: 10.1097/ALN.0b013e31824babfe

70. Chang YC, Liu CL, Chen MJ, Hsu YW, Chen SN, Lin CH, et al. Local Anesthetics Induce Apoptosis in Human Breast Tumor Cells. Anesth Analg (2014) 118:116-24. doi: 10.1213/ANE.0b013e3182a94479

71. Yoon JR, Whipple RA, Balzer EM, Cho EH, Matrone MA, Peckham M, et al. Local Anesthetics Inhibit Kinesin Motility and Microtentacle Protrusions in Human Epithelial and Breast Tumor Cells. Breast Cancer Res Treat (2011) 129:691-701. doi: 10.1007/s10549-010-1239-7

72. Lirk P, Berger R, Hollmann MW, Fiegl H. Lidocaine Time- and DoseDependently Demethylates Deoxyribonucleic Acid in Breast Cancer Cell Lines In Vitro. Br J Anaesth (2012) 109:200-7. doi: 10.1093/bja/aes128

73. Chamaraux-Tran TN, Mathelin C, Aprahamian M, Joshi GP, Tomasetto C, Diemunsch P, et al. Antitumor Effects of Lidocaine on Human Breast Cancer Cells: An In Vitro and In Vivo Experimental Trial. Anticancer Res (2018) 38:95-105. doi: 10.21873/anticanres.12196

74. Johnson MZ, Crowley PD, Foley AG, Xue C, Connolly C, Gallagher HC, et al. Effect of Perioperative Lidocaine on Metastasis After Sevoflurane or Ketamine-Xylazine Anaesthesia for Breast Tumour Resection in a Murine Model. Br J Anaesth (2018) 121:76-85. doi: 10.1016/j.bja.2017.12.043

75. Freeman J, Crowley PD, Foley AG, Gallagher HC, Iwasaki M, Ma D, et al. Effect of Perioperative Lidocaine and Cisplatin on Metastasis in a Murine Model of Breast Cancer Surgery. Anticancer Res (2018) 38:5599-606. doi: 10.21873 /anticanres.12894

76. Galos EV, Tat TF, Popa R, Efrimescu CI, Finnerty D, Buggy DJ, et al. Neutrophil Extracellular Trapping and Angiogenesis Biomarkers After Intravenous or Inhalation Anaesthesia With or Without Intravenous Lidocaine for Breast Cancer Surgery: A Prospective, Randomised Trial. $\mathrm{Br}$ J Anaesth (2020) 125:712-21. doi: 10.1016/j.bja.2020.05.003

77. Gong X, Dan J, Li F, Wang L. Suppression of Mitochondrial Respiration With Local Anesthetic Ropivacaine Targets Breast Cancer Cells. J Thorac Dis (2018) 10:2804-12. doi: 10.21037/jtd.2018.05.21

78. Li R, Xiao C, Liu H, Huang Y, Dilger JP, Lin J. Effects of Local Anesthetics on Breast Cancer Cell Viability and Migration. BMC Cancer (2018) 18:666. doi: 10.1186/s12885-018-4576-2

79. Jiang A, Zhao H, Cai J, Jiang WG. Possible Effect of Muscle-Relaxant Anaesthetics on Invasion, Adhesion and Migration of Breast Cancer Cells. Anticancer Res (2016) 36:1259-65.

80. Huang Y, Pan L, Helou K, Xia Q, Parris TZ, Li H, et al. Mechanical Ventilation Promotes Lung Metastasis in Experimental 4T1 Breast Cancer LungMetastasized Models. Cancer Manag Res (2018) 10:545-55. doi: 10.2147/ CMAR.S142650

81. Greten FR, Grivennikov SI. Inflammation and Cancer: Triggers, Mechanisms, and Consequences. Immunity (2019) 51(1):27-41. doi: 10.1016/j.immuni.2019.06.025

82. Mineo TC, Sellitri F, Vanni G, Gallina FT, Ambrogi V. Immunological and Inflammatory Impact of Non-Intubated Lung Metastasectomy. Int J Mol Sci (2017) 18:1466. doi: 10.3390/ijms18071466

83. Kim R, Kawai A, Wakisaka M, Funaoka Y, Nishida Y, Yasuda N, et al. Outcomes of Outpatient Breast Cancer Surgery at a Private Breast Clinic. Breast J (2018) 24:628-32. doi: 10.1111/tbj.13012

84. Kim R, Kawai A, Wakisaka M, Sawada S, Shimoyama M, Yasuda N, et al. Outpatient Breast-Conserving Surgery for Breast Cancer: Use of Local and Intravenous Anesthesia and/or Sedation May Reduce Recurrence and Improve Survival. Ann Med Surg (Lond) (2020) 60:365-71. doi: 10.1016/ j.amsu.2020.10.072

85. Fisher B. Laboratory and Clinical Research in Breast Cancer: A Personal Adventure-The David A. Karnofsky Memorial Lecture. Cancer Res (1980) 40:3863-74.

86. Sistigu A, Musella M, Galassi C, Vitale I, De Maria R. Tuning Cancer Fate: Tumor Microenvironment's Role in Cancer Stem Cell Quiescence and
Reawakening. Front Immunol (2020) 11:2166:2166. doi: 10.3389/ fimmu.2020.02166

87. Kim R, Emi M, Tanabe K, Arihiro K. Tumor-Driven Evolution of Immunosuppressive Networks During Malignant Progression. Cancer Res (2006) 66:5527-36. doi: 10.1158/0008-5472.CAN-05-4128

88. Yan T, Zhang GH, Wang BN, Sun L, Zheng H. Effects of Propofol/ Remifentanil-Based Total Intravenous Anesthesia Versus SevofluraneBased Inhalational Anesthesia on the Release of VEGF-C and TGF- $\beta$ and Prognosis After Breast Cancer Surgery: A Prospective, Randomized and Controlled Study. BMC Anesthesiol (2018) 18:131. doi: 10.1186/s12871-0180588-3

89. Oh CS, Lee J, Yoon TG, Seo EH, Park HJ, Piao L, et al. Effect of Equipotent Doses of Propofol Versus Sevoflurane Anesthesia on Regulatory T Cells After Breast Cancer Surgery. Anesthesiology (2018) 129:921-31. doi: 10.1097/ ALN.0000000000002382

90. Yan T, Zhang GH, Cheng YZ, Wu LX, Liu XY, Sun YL, et al. Effects of Anesthetic Technique and Surgery on Myeloid-Derived Suppressor Cells and Prognosis in Women Who Underwent Breast Cancer Surgery: A Prospective Study. Cancer Manag Res (2019) 11:5513-22. doi: 10.2147/ CMAR.S183519

91. Hovaguimian F, Braun J, Z'graggen BR, Schläpfer M, Dumrese C, Ewald C, et al. Anesthesia and Circulating Tumor Cells in Primary Breast Cancer Patients: A Randomized Controlled Trial. Anesthesiology (2020) 133:548-58. doi: 10.1097/ALN.0000000000003409

92. Levins KJ, Prendeville S, Conlon S, Buggy DJ. The Effect of Anesthetic Technique on $\mu$-Opioid Receptor Expression and Immune Cell Infiltration in Breast Cancer. J Anesth (2018) 32:792-6. doi: 10.1007/s00540-018-2554-0

93. Lim JA, Oh CS, Yoon TG, Lee JY, Lee SH, Yoo YB, et al. The Effect of Propofol and Sevoflurane on Cancer Cell, Natural Killer Cell, and Cytotoxic T Lymphocyte Function in Patients Undergoing Breast Cancer Surgery: an. Vitro analysis BMC Cancer (2018) 18:159. doi: 10.1186/s12885-018-4064-8

94. Ní Eochagáin A, Burns D, Riedel B, Sessler DI, Buggy DJ. The Effect of Anaesthetic Technique During Primary Breast Cancer Surgery on Neutrophil-Lymphocyte Ratio, Platelet-Lymphocyte Ratio and Return to Intended Oncological Therapy. Anaesthesia (2018) 73:603-11. doi: 10.1111/ anae. 14207

95. Desmedt C, Demicheli R, Fornili M, Bachir I, Duca M, Viglietti G, et al. Potential Benefit of Intra-Operative Administration of Ketorolac on Breast Cancer Recurrence According to the Patient's Body Mass Index. J Natl Cancer Inst (2018) 110:1115-22. doi: 10.1093/jnci/djy042

96. Cui X, Zhu C, Chen P, Qu M, Zhang B, Li H. Effect of Pectoral Nerve Block Type II Under General Anesthesia on the Immune Function of Patients With Breast Cancer. Am J Surg (2020) 220:938-44. doi: 10.1016/ j.amjsurg.2020.03.008

97. Cho JS, Lee MH, Kim SI, Park S, Park HS, Oh E, et al. The Effects of Perioperative Anesthesia and Analgesia on Immune Function in Patients Undergoing Breast Cancer Resection: A Prospective Randomized Study. Int J Med Sci (2017) 14:970-6. doi: 10.7150/ijms.20064

98. Exadaktylos AK, Buggy DJ, Moriarty DC, Mascha E, Sessler DI. Can Anesthetic Technique for Primary Breast Cancer Surgery Affect Recurrence or Metastasis? Anesthesiology (2006) 105:660-4. doi: 10.1097/ 00000542-200610000-00008

99. Koonce SL, Mclaughlin SA, Eck DL, Porter S, Bagaria S, Clendenen SR, et al. Breast Cancer Recurrence in Patients Receiving Epidural and Paravertebral Anesthesia: A Retrospective, Case-Control Study. Middle East J Anesthesiol (2014) 22:567-71.

100. Enlund M, Berglund A, Andreasson K, Cicek C, Enlund A, Bergkvist L. The Choice of Anaesthetic-Sevoflurane or Propofol-and Outcome From Cancer Surgery: A Retrospective Analysis. Ups J Med Sci (2014) 119:251-61. doi: 10.3109/03009734.2014.922649

101. Starnes-Ott K, Goravanchi F, Meininger JC. Anesthetic Choices and Breast Cancer Recurrence: A Retrospective Pilot Study of Patient, Disease, and Treatment Factors. Crti Care Nurs Q (2015) 38:200-10. doi: 10.1097/ CNQ.0000000000000062

102. Tsigonis AM, Al-Hamadani M, Linebarger JH, Vang CA, Krause FJ, Johnson JM, et al. Are Cure Rates for Breast Cancer Improved by Local and Regional Anesthesia? Reg Anesth Pain Med (2016) 41:339-47. doi: 10.1097/ AAP. 0000000000000379 
103. Cata JP, Chavez-MacGregor M, Valero V, Black W, Black DM, Goravanchi F, et al. The Impact of Paravertebral Block Analgesia on Breast Cancer Survival After Surgery. Reg Anesth Pain Med (2016) 41:696-703. doi: 10.1097/AAP.0000000000000479

104. Lee JH, Kang SH, Kim Y, Kim HA, Kim BS. Effects of Propofol-Based Total Intravenous Anesthesia on Recurrence and Overall Survival in Patients After Modified Radical Mastectomy: A Retrospective Study. Korean J Anesthesiol (2016) 69:126-32. doi: 10.4097/kjae.2016.69.2.126

105. Kim MH, Kim DW, Kim JH, Lee KY, Park S, Yoo YC. Does the Type of Anesthesia Really Affect the Recurrence-Free Survival After Breast Cancer Surgery? Oncotarget (2017) 8:90477-87. doi: 10.18632/ oncotarget. 21014

106. Karanlik H, Kılıç B, Yıldırım I, Bademler S, Ozgur I, Ilhan B, et al. BreastConserving Surgery Under Local Anesthesia in Elderly Patients With Severe Cardiorespiratory Comorbidities: A Hospital-Based Case-Control Study. Breast Care (Basel) (2017) 12:29-33. doi: 10.1159/000455003

107. Huang YH, Lee MS, Lou YS, Lai HC, Yu JC, Lu CH, et al. Propofol-Based Total Intravenous Anesthesia Did Not Improve Survival Compared to Desflurane Anesthesia in Breast Cancer Surgery. PloS One (2019) 14: e0224728. doi: 10.1371/journal.pone.0224728

108. Yoo S, Lee HB, Han W, Noh DY, Park SK, Kim WH, et al. Total Intravenous Anesthesia Versus Inhalation Anesthesia for Breast Cancer Surgery: A Retrospective Cohort Study. Anesthesiology (2019) 130:31-40. doi: 10.1097/ ALN.0000000000002491

109. Shiono S, Shibata SC, Kabata D, Shintani A, Ikeda T, Fujino Y. Comparison of 1-Year Recurrence-Free Survival Between Sevoflurane and Propofol Use for General Anesthesia Management in Primary Breast Cancer Surgery. J Anesth (2020) 34:694-701. doi: 10.1007/s00540-020-02806-7

110. Enlund M, Berglund A, Ahlstrand R, Walldén J, Lundberg J, Wärnberg F, et al. Survival After Primary Breast Cancer Surgery Following Propofol or Sevoflurane General Anesthesia-A Retrospective, Multicenter, Database Analysis of 6305 Swedish Patients. Acta Anaesthesiol Scand (2020) 64:1048-54. doi: 10.1111/aas

111. Grandhi RK, Lee S, Abd-Elsayed A. The Relationship Between Regional Anesthesia and Cancer: A Metaanalysis. Ochsner J (2017) 17:345-61.
112. Yap A, Lopez-Olivo MA, Dubowitz J, Hiller J, Riedel B. Global Onco-Anesthesia Research Collaboration Group. Anesthetic Technique and Cancer Outcomes: A Meta-Analysis of Total Intravenous Versus Volatile Anesthesia. Can J Anaesth (2019) 66:546-61. doi: 10.1007/s12630-019-01330-x

113. Karmakar MK, Samy W, Lee A, Li JW, Chan WC, Chen PP, et al. Survival Analysis of Patients With Breast Cancer Undergoing a Modified Radical Mastectomy With or Without a Thoracic Paravertebral Block: A 5-Year Follow-Up of a Randomized Controlled Trial. Anticancer Res (2017) 37:5813-20. doi: 10.21873/anticanres.12024

114. Sessler DI, Pei L, Huang Y, Fleischmann E, Marhofer P, Kurz A, et al. Breast Cancer Recurrence Collaboration. Recurrence of Breast Cancer After Regional or General Anaesthesia: A Randomised Controlled Trial. Lancet (2019) 394:1807-15. doi: 10.1016/S0140-6736(19)32313-X

115. Dubowitz JA, Cata JP, De Silva AP, Braat S, Shan D, Yee K, et al. Global Onco-Anaesthesia Research Collaboration Group. Volatile Anaesthesia and Peri-Operative Outcomes Related to Cancer: A Feasibility and Pilot Study for a Large Randomised Control Trial. Anaesthesia (2021) 76:1198-206. doi: 10.1111 /anae. 15354

Conflict of Interest: The authors declare that the research was conducted in the absence of any commercial or financial relationships that could be construed as a potential conflict of interest.

Publisher's Note: All claims expressed in this article are solely those of the authors and do not necessarily represent those of their affiliated organizations, or those of the publisher, the editors and the reviewers. Any product that may be evaluated in this article, or claim that may be made by its manufacturer, is not guaranteed or endorsed by the publisher.

Copyright (c) $2022 \mathrm{Kim}, \mathrm{Kawai}$, Wakisaka and Kin. This is an open-access article distributed under the terms of the Creative Commons Attribution License (CC BY). The use, distribution or reproduction in other forums is permitted, provided the original author(s) and the copyright owner(s) are credited and that the original publication in this journal is cited, in accordance with accepted academic practice. No use, distribution or reproduction is permitted which does not comply with these terms. 